\title{
Purification and characterization of the nuclear RNase P holoenzyme complex reveals extensive subunit overlap with RNase MRP
}

\author{
Joel R. Chamberlain, ${ }^{1}$ Yoon Lee, ${ }^{2}$ William S. Lane, ${ }^{3}$ and David R. Engelke ${ }^{1,2,4}$ \\ ${ }^{1}$ Program in Cellular and Molecular Biology, 2Department of Biological Chemistry, University of Michigan Medical School, \\ Ann Arbor, Michigan 48109-0606 USA; ${ }^{3}$ Harvard M icrochemistry Facility, Cambridge, Massachusetts 02138 USA
}

\begin{abstract}
Ribonuclease P (RNase P) is a ribonucleoprotein enzyme that cleaves precursor tRNA transcripts to give mature 5' ends. RNase P in eubacteria has a large, catalytic RNA subunit and a small protein subunit that are required for precursor tRNA cleavage in vivo. Although the eukaryotic holoenzymes have similar, large RNA subunits, previous work in a number of systems has suggested that the eukaryotic enzymes require a greater protein content. We have purified the Saccharomyces cerevisiae nuclear RNase P to apparent homogeneity, allowing the first comprehensive analysis of an unexpectedly complex subunit composition. Peptide sequencing by ion trap mass spectrometry identifies nine proteins that copurify with the nuclear RNase $P$ RNA subunit, totaling 20-fold more protein than in the bacterial enzyme All of these proteins are encoded by genes essential for RNase P activity and for cell viability. Previous genetic studies suggested that four proteins might be subunits of both RNase P and RNase MRP, the related rRNA processing enzyme We demonstrate that all four of these proteins, Poplp, Pop3p, Pop4p, and Rpplp, are integral subunits of RNase P. In addition, four of the five newly identified protein subunits, Pop5p, Pop6p, Pop7p, and Pop8p, also appear to be shared between RNase P and RNase MRP. Only one polypeptide, Rpr2p, is unique to the RNase P holoenzyme by genetic depletion and immunoprecipitation studies. The large increase in the number of protein subunits over eubacterial RNase $P$ is consistent with an increase in functional complexity in eukaryotes. The degree of structural similarity between nuclear RNase $P$ and RNase MRP suggests that some aspects of their functions in pre-tRNA and pre-rRNA processing pathways might overlap or be coordinated.
\end{abstract}

[Key Words: Ribonuclease P; ribonuclease MRP; RNP; tRN A]

Received February 19, 1998; revised version accepted A pril 3, 1998.

Precursor tRNAs (pre-tRNAs) are processed at their 5' and $3^{\prime}$ ends to yield mature tRNAs. Ribonuclease $P$ (RN ase $\mathrm{P}$ ) is the enzyme responsible for the $5^{\prime}$ endonucleolytic cleavage in eubacteria, archaea, and eukaryotes (Altman et al. 1995; Pace and Brown 1995; Chamberlain et al. 1996b). In most instances the enzyme is composed of both RNA and protein, but it is the RNA subunit of the eubacterial RN ase $P$ that is capable of both recognizing and cleaving substrates efficiently and accurately (Guerrier-Takada et al. 1983). The protein component serves as a cofactor and is absolutely required in vivo (Reich et al. 1988). Although the eubacterial RNAs are divergent in primary sequence, characterization of the RNA structure has resulted in proposed tertiary models of the RN ase P RN A subunit (Westhof and Altman 1994; Harris et al. 1997). Experimental conditions that would allow catalysis by the archaeal and eukaryotic RN ase P RNAs have not been defined, although the archaeal and eukaryotic RN As appear to fold in a secondary structure resembling the eubacterial RNA subunit (Forster and Altman 1990; Tranguch et al. 1994; Chen and Pace 1997). The eubacterial RNA subunit (350-410 nucleotides) is similar in size to the eukaryotic nuclear RN A (280-380 nucleotides), but the protein content of the eukaryotic enzyme is much greater, estimated to be $50 \%$ $70 \%$ of the eukaryotic holoenzyme as compared to $10 \%$ of the eubacterial enzyme (Lawrence et al. 1987; Doria et al. 1991; Jayanthi and Van Tuyle 1992). The increase in protein in the eukaryotic enzyme suggests that the eukaryotic RN ase $P$ may represent a transition from an early RNA enzyme, still maintained in bacteria, to an enzyme dependent on protein for activity. The large increase in the protein compl exity might also be necessary for function in the increased organizational complexity of the eukaryotic cell. 
RN ase $P$ activities are found in the nuclei (Bartki ewicz et al. 1989; Lee and Engelke 1989; Doria et al. 1991), mitochondria (Doersen et al. 1985; Hollingsworth and M artin 1986; Y. Lee et al. 1996), and chloroplasts (Thomas et al. 1995) of eukaryotes. Purifications of Saccharomyces cerevisiae mitochondrial and Schizosaccharomyces pombe nuclear RN ase $\mathrm{P}$ identified single proteins of $\sim 100 \mathrm{kD}$ that cofractionated with RN ase P activity (M orales et al. 1992; Zimmerly et al. 1993). The nuclear gene encoding the S. cerevisiae mitochondrial protein subunit RPM 2 has been found essential and necessary for mitochondrial pre-tRNA processing (Dang and M artin 1993). Other mitochondrial enzymes might have higher protein content, however. The mitochondrial enzyme from Aspergillus nidulans appears to have several proteins that cofractionate with activity (Y.C. Lee et al. 1996).

Several polypeptides have been implicated in S. cerevisiae nucl ear RN ase $\mathrm{P}$ function by direct and indirect experiments. Three of these proteins were first identified by genetic methods that were intended to identify proteins associated with the activity of a related ribonucleoprotein enzyme, RNase mitochondrial RNA processing (RN ase MRP). RN ase MRP has an essential RNA subunit that is evolutionarily related to $R N$ ase $P$ (Gold et al. 1989; M orrissey and Tollervey 1995) and of similar size. This enzyme, however, cleaves rRNA precursors found in nucleoli (Shuai and Warner 1991; Schmitt and Clayton 1993; Chu et al. 1994; Lygerou et al. 1996) and has also been implicated in mitochondrial replication (Stohl and Clayton 1992). The three genes originally identified as affecting RNase MRP function, POP1, POP3, and POP4 (Lygerou et al. 1994; Chu et al. 1997; Dichtl and Tollervey 1997) encode proteins that are al so required for RN ase P activity in vivo. Immunoprecipitation of these Pop proteins shows that they are physically associated with both RN ase P and RN ase M RP RNAs. A nother candidate protein subunit, Rpplp, recently has been identified in yeast by its homology with a human protein, Rpp30, that cofractionates with HeLa cell RN ase P along with a number of other polypeptides (Eder et al. 1997). Like the Pop proteins, depletion and immunoprecipitation studies suggest that Rpplp is a subunit of both RN ase $P$ and RN ase M RP (Stolc and Altman 1997). N one of these subunits has obvious homology with either the 14-kD bacterial RN ase $P$ subunit $C 5$ (Hansen et al. 1985) or the 105-kD mitochondrial RN ase $P$ subunit $R p m 2 p$ (Dang and Martin 1993). Only one protein, Snmlp, has been identified that is physically associated with only RN ase M RP (Schmitt and Clayton 1994).

Confirmation of the Pop proteins as integral components of the RNase P holoenzyme has been difficult. Both enzymes might be part of a large complex in vivo such that mutations in subunits of either enzyme could indirectly affect the activity of the other. If the two enzymes are associated, it would be expected that they colocalize in cells, but in situ hybridization with probes specific for RNase P or RNase MRP probes has given conflicting results. The established cellular location of RN ase MRP is primarily nucleolar, where it functions in pre-rRN A processing (Jacobson et al. 1995; Matera et al.
1995). There is disagreement in reports as to whether mammalian RN ase P RNA is primarily nucleoplasmic after transient nucleolar association (Jacobson et al. 1997) or is mostly found in focused loci at the edges of nucleoli (M atera et al. 1995; B. Lee et al. 1996). N uclear $R N$ ase $P$ and RN ase M RP have been shown to have similar chromatographic properties but can be well separated by high-resolution anion exchange chromatography (Chamberlain et al. 1996a; Lygerou et al. 1996). It has not been previously clear from these biochemical separations which subunits are integral to the RN ase P holoenzyme.

Given the complexity of candidates for RN ase $\mathrm{P}$ and RN ase M RP subunits and limited information regarding the structure and function of the nucleolar processing enzymes, we have undertaken the purification of nucl ear RN ase $P$ from $S$. cerevisiae. Partial purification previously identified the RNA subunit of nuclear RN ase $P$, separated RN ase $P$ from RN ase MRP, and suggested a link between RN ase $P$ and pre-rRNA processing (Lee and Engel ke 1989; Lee et al. 1991; Chamberlain et al. 1996a). In this report we present the purification of RN ase $\mathrm{P}$ to apparent homogeneity. We identify nine proteins that copurify with activity, confirm their functional association with RN ase $P$, and determine which newly identified RNase P proteins are associated with RN ase MRP activity.

\section{Results}

Ten subunits copurify with nuclear RNase P activity

The early steps in the purification of nuclear RN ase $P$ followed essentially those described previously (Chamberlain et al. 1996a). Cellular extract was prepared from 100 liters of yeast culture and high-salt extraction was performed on the particulate fractions that included the nuclei. Ion exchange chromatography was initiated by step elution from SP-Sepharose and DEAE-cellul ose be fore attempting high-resolution chromatography by FPLC. Linear salt gradient el ution was used with Mono $\mathrm{Q}$ that resulted in a peak of $\mathrm{RN}$ ase $\mathrm{P}$ activity between 0.4 and $0.5 \mathrm{M} \mathrm{KCl}$. The activity from $\mathrm{M}$ ono $\mathrm{Q}$ was subjected to high-resolution M ono S chromatography. RN ase P enzymatic activity eluted between 0.2 and $0.3 \mathrm{M} \mathrm{KCl}$ in a linear salt gradient. The last step in the purification was velocity sedimentation in $15 \%-25 \%$ glycerol. RN ase $P$ mi grated as a large complex and was well separated from contaminants that formed the majority of the input material of the glycerol gradients.

Table 1 summarizes the steps for purification of RN ase P activity. The specific activity was increased $\sim 4000$-fold over the starting yeast extract by completion of the Mono S chromatography step. Beyond this stage protein concentrations were too dilute for reliable spectrophotometric measure, and protein concentration in the glycerol gradient peak fractions had to be estimated based on quantitation of the RN A subunit. Known quantities of RN ase P RN A synthesized in vitro were loaded in parallel with RNA from glycerol gradient peak frac- 
Chamberlain et al.

Table 1. Isolation and enrichment of RNase P

\begin{tabular}{|c|c|c|c|c|c|}
\hline Fraction & Volume (ml) & $\begin{array}{l}\text { Total units } \\
\left(10^{3}\right)^{\mathrm{a}}\end{array}$ & $\begin{array}{l}\text { Total protein } \\
(\mathrm{mg})\end{array}$ & $\begin{array}{l}\text { Sp. Act. } \\
\text { (U/mg) }\end{array}$ & $\begin{array}{c}\text { Enrichment } \\
\text { (fold) }\end{array}$ \\
\hline Yeast extract & 498 & 41.1 & 23,700 & 1.74 & 1 \\
\hline SP-Sepharose & 775 & 53.9 & 852 & 63.3 & 36 \\
\hline DE52 & 94 & 16.4 & 167 & 97.9 & 56 \\
\hline Resource Q & 10.5 & 8.1 & 11.7 & 693 & 400 \\
\hline Resource S & 2.9 & 2.3 & 0.3 & 6760 & 3900 \\
\hline Glycerol gradient peak & 16 & 0.65 & {$[0.001]^{\mathrm{b}}$} & {$[650,000]^{\mathrm{b}}$} & {$[370,000]^{\mathrm{b}}$} \\
\hline
\end{tabular}

${ }^{a} 1$ Unit $=$ relative RN ase $P$ activity required to convert $10 \%$ of 1.0 pmole of pre-tRN A ${ }^{A S P}$ in 15 min under standard assay conditions. ${ }^{b}$ Quantity of total protein in glycerol gradient peak estimated on the basis of total RNA (see Materials and Methods).

tions on a denaturing polyacrylamide gel and were analyzed by N orthern bl ot using an antisense RN ase P RN A probe. Although we cannot be sure on the basis of these data that each protein subunit is present in a molar ratio of 1 , if we assume a 1:1 molar ratio of RNA to protein subunits, the final total protein content is $\sim 1 \mu \mathrm{g}$. The 100 -fold purification resulting from vel ocity sedimentation is an estimate but is consistent with protein abundance by both silver and by Coomassie brilliant blue staining (see below).

The peak of RN ase $P$ activity from the final glycerol gradient fractions (Fig. 1A) coincided exactly with the peak of RN ase P RN A (RPR I RN A) detected by N orthern blots (Fig. 1B). A single form of the RPR1 RNA was observed (Fig. 1B), corresponding to the mature 369-nucleo- ti de form generated by $5^{\prime}$ and 3 ' processing (Lee and Engel ke 1989). The pre-RPR 1 form, removed by the earlier M ono Q separation (Chamberlain et al . 1996a), appeared to be assembled into a ribonucleoprotein complex, as judged by its copurification with the mature form through most chromatographic steps. As expected in this final glycerol gradient, we were unable to detect preRPR1, the RN ase MRP RNA subunit, or the mitochondrial RNase P RNA subunit.

Analysis of the same glycerol gradient fractions by SDS-PAGE (Fig. 1C) showed one RN A (upper band) and 6 bands of protein coincident with the peak of RNase $P$ activity and with RPR1-containing fractions (lanes 510). The intact, large RN A appeared as an orange-brown color predicted for silver staining of nucleic acid. This
Figure 1. RNase $P$ activity and RPRI RNA comigrate with a defined set of proteins in glycerol gradient vel ocity sedimentation. Contents of individual fractions from the final purification step, glycerol gradient sedimentation, were analyzed to locate RN ase $P$ activity and the RN A subunit, and to determine the profile of proteins that coincide with the enzyme. (A) RN ase $P$ activity was assayed by cleaving ${ }^{32} \mathrm{P}$-labeled pre-tRN $\mathrm{A}^{\mathrm{Asp}}$ to give tRN A ${ }^{\mathrm{Asp}}$ and the $5^{\prime}$ leader sequence. RNA products were separated el ectrophoretically through $12 \%$ denaturing polyacrylamide and analyzed quantitatively by Phosphorlmager. Fraction numbers are provided at the top; the input to the gradient is marked in. Sedimentation was from right (higher-numbered fractions) to left (lower-numbered fractions). (B) RN A extracted from fractions was separated on $8 \%$ denaturing polyacrylamide gels, blotted to nylon membranes, and probed with ${ }^{32} \mathrm{P}$-labeled RPR 1 antisense RNA to detect the RN ase P RNA subunit. Amounts of RNA were estimated by quantitative comparison of the signal strength to known quantities of RPR 1 sense-strand RNA prepared by in vitro transcription and blotted in parallel (not shown). (C) Protein and nucleic acid contents of fractions were visualized by denaturing PAGE in the presence of SDS and staining with silver. (Lane M) contains protein size markers with molecular mass (in KD) at right. The largest band comigrates with RPR1 RNA and does not stain with Coomassie brilliant blue in preparative gels, suggesting that it contains only the RN A subunit. The identities of proteins in lower regions of the gel were determined by excision of Coomassie-staining bands from a preparative-scale gel and exhaustive peptide analysis by ion trap mass spectrometry as described in M aterials and M ethods. Two bands migrating at 100 and 80 kD contained only Poplp protein. The region of the two lowest visi ble bands contained six distinct RN ase $P$ subunits. The positions of the confirmed protein subunits relative to the polypeptide pattern are indicated at left; nomenclature is explained in the text and in Table 1. 
band did not appear with Coomassie brilliant blue staining of subsequent preparative polyacrylamide gels, and its identity as the RN ase P RN A also was confirmed by blotting and hybridization of an antisense RPR1 RNA probe (data not shown). In addition to the RN A, multiple protein bands appeared as 100, 80,32, 30, 20, and $18 \mathrm{kD}$ relative to protein standards. It appeared likely that all of these polypeptides are associated with a single large complex because of their comigration at this position of high apparent molecular mass in the gradient. No additional, prominent protein bands overlap the peak of the RNase $\mathrm{P}$ complex, al though many proteins are clearly visible in higher numbered fractions (Fig 1C, lanes 1226) corresponding to lighter gradient fractions.

Protein sequence determination by ion trap mass spectrometry

Because the protein sample was limiting (4 pmoles), amino acid sequence determination of protein subunits excised from preparative SDS-PAGE gels was accomplished by electrospray ionization ion trap mass spectrometry (see $M$ aterials and $M$ ethods). Exhaustive analysis of peptide fragments in gel slices identified a total of 9 proteins in the sample that were confirmed to be RNase $P$ subunits by genetic depletion studies. All of the polypeptides were identified within the $S$. cerevisiae genome database (SGD) (Cherry et al. 1996; Goffeau et al. 1996) using Sequest and FASTA algorithms (Lipman and Pearson 1985; Pearson and Lipman 1988; Eng et al. 1994). Previously unidentified subunits were named according to whether they were shown by depletion and immunoprecipitation (see below) to be specific to RN ase $P(R p r 2 p)$ or al so necessary for function of RN ase M RP (Pop5p, Pop6p, Pop7p, and Pop8p). The SDS-PAGE migrations of the RNase $P$ subunits are labeled in Figure $1 \mathrm{C}$, and a summary of all subunits is shown in Table 2 .
The largest protein, estimated by SDS-PAGE to be 100 $k D$, was Poplp. This protein previously was shown to be associated with both RN ase P and RN ase MRP from a functional genetic screen (Lygerou et al. 1994). The 80$\mathrm{kD}$ protein band also contained only Poplp, and the recovered tryptic peptides were consistent with this protein missing the carboxy-terminal $20 \mathrm{kD}$ found in fulllength Poplp. It is not possible from current samples to determine whether this $80-\mathrm{kD}$ form is an artifact produced by proteolysis during purification or an alternative product of the POP1 gene incorporated as a subunit. This question will be addressed once antibodies to Poplp can be obtained and used to probe the subunit prior to purification. The protein with an apparent migration at a molecular mass corresponding to $32 \mathrm{kD}$ was identified as the RN ase P protein Rpplp and has a predicted mass of $32.2 \mathrm{kD}$ (Stolc and Altman 1997). This protein has been characterized as an RN ase $P$ and RN ase MRP subunit from its similarity with a human protein that comigrates with RN ase P activity, Rpp30 (Eder et al. 1997), and from functional studies in yeast that reveal pre-tRN $A$ and prerRNA processing defects in cells depleted of Rpplp. The protein migrating slightly more slowly than Rpplp was yet another protein found to be functionally and physically associated with both RN ase P and RN ase MRP, Pop4p (Chu et al. 1997).

The two bands smaller than $20 \mathrm{kD}$ actual ly contained six proteins (Fig. 1C; Table 2). Pop3p was suggested previously to be a subunit of both RN ase P and RN ase MRP (Dichtl and Tollervey 1997), but the remaining five proteins were predicted products of hypothetical open reading frames (ORFs) of unknown functions. Only the protein of an estimated $19.6 \mathrm{kD}$, a product of the FU N53 gene on chromosome I, had been shown to be essential (Harris et al. 1992). All but one of these five polypeptides were found in further anal yses (T able 1; Figs. 3 and 4, see below) to affect both RN ase $P$ and RN ase M RP activities and given Pop designations (Pop5p-Pop8p). A single pro-

Table 2. Composition of the purified RNase P holoenzyme and summary of functional analysis of each protein subunit

\begin{tabular}{|c|c|c|c|c|c|c|c|c|c|c|c|}
\hline \multirow[b]{2}{*}{ Gene } & \multirow{2}{*}{$\begin{array}{l}\text { Subunit } \\
\text { type }\end{array}$} & \multirow{2}{*}{$\begin{array}{l}\text { Estimated } \\
\text { size } \\
(\mathrm{kd})\end{array}$} & \multicolumn{2}{|c|}{$\begin{array}{l}\text { Processing defect } \\
\text { with subunit depletion }\end{array}$} & \multicolumn{3}{|c|}{$\begin{array}{l}\text { Reduction of RNA } \\
\text { with subunit depletion }\end{array}$} & \multicolumn{3}{|c|}{$\begin{array}{c}\text { Immunoprecipitated } \\
\text { RNA }\end{array}$} & \multirow[b]{2}{*}{ Reference $^{a}$} \\
\hline & & & pre-tRNA & pre-rRNA & pre-P & $\mathrm{P}$ & MRP & pre-P & $\mathrm{P}$ & MRP & \\
\hline RPR1 & RNA & 120 & - & - & - & - & - & - & - & - & Lee et al. (1991) \\
\hline POP1 & protein & 100.5 & $\mathrm{Y}$ & $\mathrm{Y}$ & $Y^{b}$ & $\mathrm{Y}$ & $\mathrm{Y}$ & $\mathrm{Y}$ & $\mathrm{Y}$ & Y & Lygerou et al. (1994) \\
\hline POP4 & protein & 32.9 & $Y$ & $Y$ & $\mathrm{~N}$ & $\mathrm{Y}$ & $Y$ & $Y$ & Y & Y & Chu et al. (1997) \\
\hline RPP1 & protein & 32.2 & $\mathrm{Y}$ & $\mathrm{Y}$ & $\mathrm{N}$ & $\mathrm{Y}$ & $\mathrm{Y}$ & $\mathrm{Y}$ & $\mathrm{Y}$ & $\mathrm{Y}$ & Stolc and Altman (1997) \\
\hline POP3 & protein & 22.6 & $Y$ & $Y$ & $\mathrm{~N}$ & $\mathrm{~N}$ & $\mathrm{~N}$ & $Y$ & $\mathrm{Y}$ & $Y$ & Dicht and Tollervey (1997) \\
\hline POP5 & protein & 19.6 & $Y$ & $Y$ & $\mathrm{~N}$ & $\mathrm{Y}$ & $Y$ & $Y$ & Y & Y & this report \\
\hline POP6 & protein & 18.2 & $Y$ & Y & $\mathrm{N}$ & $\mathrm{Y}$ & $\mathrm{Y}$ & $\mathrm{N}$ & $\mathrm{N}$ & $\mathrm{N}$ & this report \\
\hline RPR2 & protein & 16.4 & $Y$ & $\mathrm{~N}$ & $\mathrm{~N}$ & $\mathrm{Y}$ & $\mathrm{N}$ & Y & $\mathrm{Y}$ & $\mathrm{N}$ & this report \\
\hline POP7 & protein & 15.8 & Y & Y & $\mathrm{N}$ & Y & $Y$ & Y & $\mathrm{N}$ & Y & this report \\
\hline POP8 & protein & 15.5 & $\mathrm{Y}$ & $\mathrm{N}$ & $\mathrm{N}$ & $\mathrm{Y}$ & $\mathrm{Y}$ & Y & $\mathrm{Y}$ & $\mathrm{Y}$ & this report \\
\hline
\end{tabular}

(Y) Yes; (N) no; (pre) precursor.

IInformation for Poplp, Pop3p, Pop4p, and Rpplp are derived from the references cited. The information reported for the remaining protein subunits is shown in Figs. 3 and 4.

${ }^{\mathrm{b}} \mathrm{A}$ pop1 temperature-sensitive strain was examined at a nonpermissive temperature for RN A reduction. Relative to the mature RN ase P RN A the precursor RN ase P RN A levels declined less rapidly, and it is unclear whether this depl etion is a result of the general decline of functional RNA levels under this condition. 
tein was specific for RN ase $P$ and the gene is named RPR2 (RNase $\underline{P}$ ribonucleoprotein-2) according to our original nomenclāture for yeast nuclear RN ase $P$ subunits.

The RNase P subunit gene products are essential for spore viability

To determine whether the five previously uncharacterized polypeptides were essential cellular components, the genes encoding the candidate RN ase $\mathrm{P}$ proteins were disrupted with a $\mathrm{kan}^{\mathrm{r}}$ gene in diploid S. cerevisiae (Fig. 2A). The $\mathrm{kan}^{r}$ gene was generated as a PCR fragment with 50 bp of flanking homol ogous sequences to the gene candidate for disruption. Transformation of diploids and subsequent homol ogous recombination resulted in a diploid strain with only one functional copy of the gene of interest. Sporulation and tetrad analysis of resultant haploid spores revealed a 2:2 segregation of spore viability with kanamycin resistance in all cases, indicating that all protein products were essential (Fig. 2B).

Depletion of RNase P candidate proteins indicates they are necessary for RNase $P$ activity in vivo

To test for function of the candi date RN ase $P$ subunits as components of RN ase $P$ and RN ase M RP activities in the cell, their expression was placed under the control of the GAL1 promoter (Fig. 2A). The ORFs to be expressed were inserted in a plasmid with the GAL 1 promoter upstream and the CYCl terminator placed downstream. Transformation of the disrupted diploid, followed by sporulation and tetrad anal ysis of the resultant spores, yielded a haploid yeast strain containing the sole copy of the gene of interest under GAL promoter control of expression. Shift of cultures to glucose medium depl eted the protein gene products, with maximum effect on growth and RNA levels reached by $12 \mathrm{hr}$.

RNA biogenesis and processing defects resulting from depletion of these proteins were assessed by Northern bl ot analysis of RN A recovered from each strain at 0 and $28 \mathrm{hr}$ after the shift to glucose-containing media (Fig. 3). The signal recognition particle RNA (scR1) was probed as a normalization control. The nucleolytic processing intermediates expected for the pre-tRNA ${ }^{\text {Leu }}$ and $5.8 \mathrm{~S}$ pre-rRNA region in either wild-type or RN ase P-deficient cells are represented in the schematic shown in Figure 3A. The wild-type strain does not accumulate significant levels of pre-tRNA ${ }^{\text {Leu }}$ either before or after the shift to glucose. In contrast, the control placing the previously characterized Rpplp subunit in the Gal-driven expression vectors does show a low-level pre-tRNA accumulation even when grown in galactose, with a significant increase in pre-tRN As after depletion of Rpplp in glucose. This result was typical of pre-tRNA accumulation for all of the newly identified subunits as well. Despite minor accumulation of tRNA precursors in strains where subunits were expressed from the GAL
Figure 2. All of the newly identified protein subunit candidates are encoded by essential genes. Four of the proteins that copurify with RN ase P activity (Pop1p, Rpp1p, Pop4p, and Pop3p) had been identified previously as candidate RN ase P subunits, and their genes had been shown to be essential. The genes for the remaining five subunits (Pop5p, Pop6p, Rpr2p, Pop7p, and Pop8p) were tested to determine whether they were essential for viability and if depletion of their gene products affected RN ase $\mathrm{P}$ or RN ase MRP function. (A) The experimental design for deleting the coding regions and substituting a gene under the regulation of a GAL1 promoter is shown schematically. Homologous recombination was used to replace one copy of each coding region in diploids with a gene for kanamycin resistance. The resulting heterodiploids were first sporulated and tested for spore viability. B shows that all tetrads segregated as two viable and two nonviable spores, the result expected for essential genes. The diagram also shows a schematic for creation of a haploid strain in which the genomic copy of the gene of interest is disrupted, and production of the gene product from a plasmid is placed under Gal control for the depletion studies shown in Fig. 3. These recombinant gene products were also all made in two versions, both of which conferred viability. One version, used for the RN A blot analyses in Fig. 3, contains only the coding region for the gene. A second version, used in the immunoprecipitation experiments in Fig. 4, also contains the 8amino-acid Flag epitope at the carboxyl terminus.
$A$

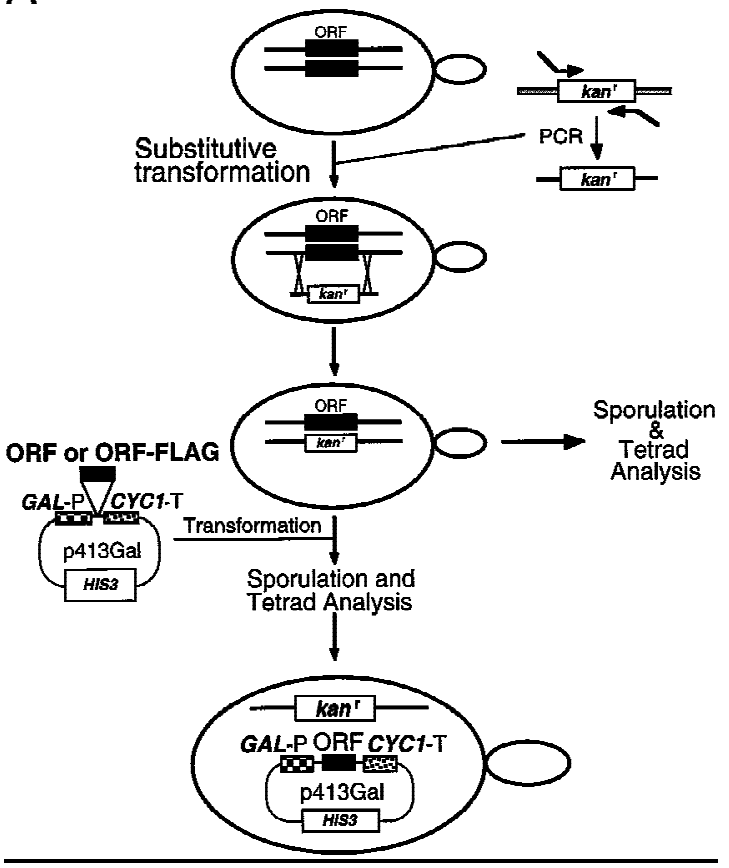

B

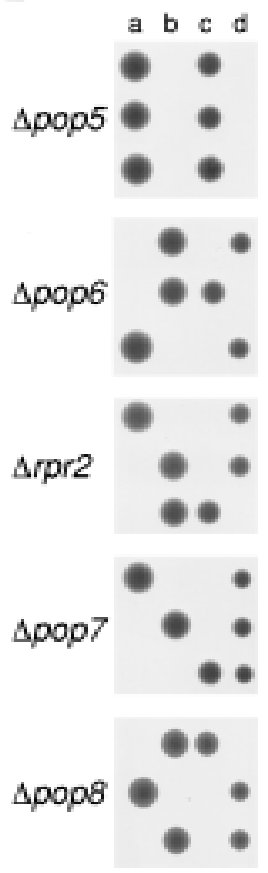


A

\section{Processing of pre-tRNA}

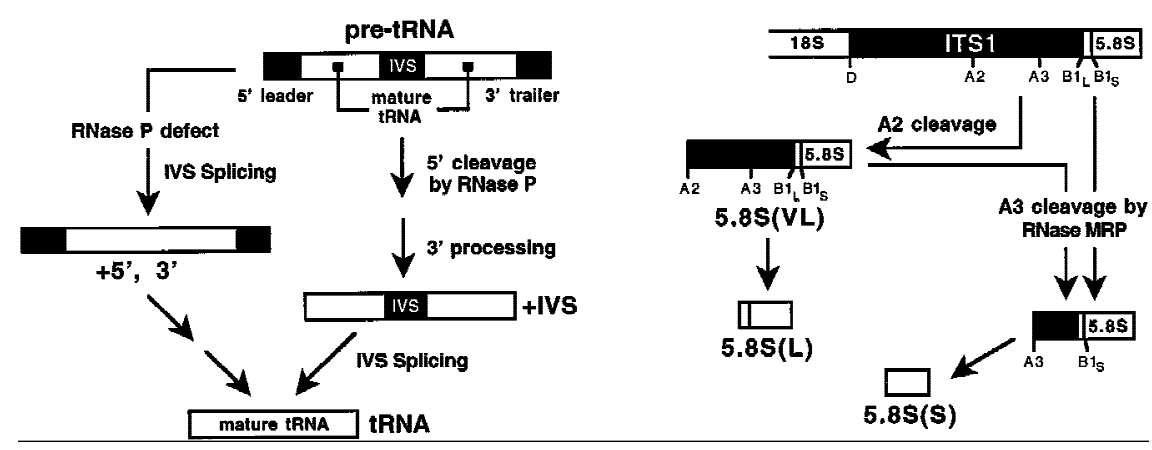

B

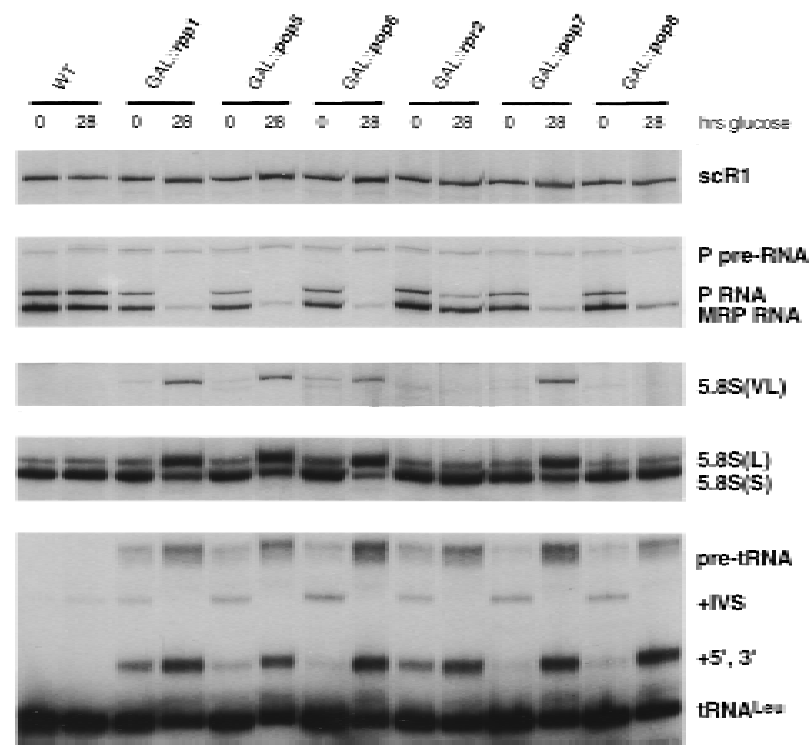

Figure 3. Depletion of the newly identified protein subunits shows that all are essential for RN ase P activity, and several are essential for RN ase M RP activity. The constructs described in Fig. 2 were used to deplete Pop5p, Pop6p, Rpr2p, Pop7p, and Pop8p by shifting to growth in glucose, which impairs growth by $6 \mathrm{hr}$ and reaches maximal effect on RNA processing in these strains by $12 \mathrm{hr}$. Growth of the parent haploid strain and depletion of the previously identified Rpplp subunit were used as controls. Steady-state levels of several different RNA types were determined at 0 and $28 \mathrm{hr}$ after the shift to glucose. Strain names (GAL::gene name) indicate the subunit that is under Gal control in the strain. (A) The expected products for processing of pre-tRNA $A^{\text {Leu3 }}$ are shown for a strain with normal or defective nuclear RN ase P. N ucleolytic processing normally proceeds at the $5^{\prime}$ end, at the $3^{\prime}$ end, and at intron removal. RN ase $P$ defects lead to an increase in intron removal prior to terminal processing $\left(+5^{\prime}\right.$, $+3^{\prime}$ intermediate). The expected products for processing of 5.8S rRN A are shown for a strain with normal participation by RN ase MRP or a deficiency in RNase MRP. Mutations cause accumulation of very long $(V L)$ and long (L) forms of $5.8 S$ at the expense of the short (S) form. (B) Whole cell RNA samples were prepared at 0 or $28 \mathrm{hr}$ after shifting to glucose to deplete the indicated subunits. RN As were separated by electrophoresis though denaturing polyacrylamide gels, el ectroblotted to nylon membranes, and probed to detect the indicated RNAs. Panels are taken from a single bl ot exposed to the following ${ }^{32} \mathrm{P}$-labeled probes (from the top): scR1 detects signal recognition particle RN A that should not be affected by either RN ase P or RN ase MRP defects; RN ase P RN A detects both mature and precursor forms; RN ase MRP RNA that detects a single form of the RNA; 5.8S rRN A detects the $S, L$, and VL forms; and tRN $A^{\text {Leu3 }}$ detects the mature and all precursr forms. Depletion of all putative subunits strongly affects pre-tRN A processing. Effects on levels of RN ase P RNA, RN ase MRP RN A, and 5.8S rRN A-containing intermediates are variable with different subunit depletions and are discussed in the text.

promoter at 0 time points, depletion of the candidate RN ase $P$ subunits for glucose resulted in increased accumulation of pre-tRN A ${ }^{\text {Leu }}$ typical of an RN ase P mutant (Lee et al. 1991). A pre-tRN A ${ }^{\text {Leu }}$ probe showed accumulation of the primary transcript ("pre-tRN A") and spliced but not end-processed pre-tRN $A^{\text {Leu }}\left(+5^{\prime},+3^{\prime}\right)$. As noted previously, end processing normally precedes splicing in the pre-tRNA maturation pathway, but accumulation of the $+5^{\prime},+3^{\prime}$ intervening sequence (IVS) intermediate in $\mathrm{RN}$ ase $\mathrm{P}$ mutants suggests that the processing order is not obligatory.

RNase $\mathrm{P}$ protein subunit depletions differentially affect the endogenous levels of RNase $P$ and RNase MRP RNAS

The Northern blot described above was also probed for
RN ase $P$ and RN ase MRP RN A subunits (Fig. 3B). As observed previously upon depletion of Poplp, Pop4p, and Rpplp proteins (Lygerou et al. 1994; Chu et al. 1997; Stolc and Altman 1997), a decrease in the levels of both mature RN ase $P$ and RN ase M RP RN As was observed for four of the five newly identified RNase $P$ proteins: Pop5p, Pop6p, Pop7p, and Pop8p. Depletion of a single subunit, Rpr2p, resulted in al most complete loss of the RN ase $P$ RN A, but a relatively small reduction of RN ase MRP RN A (twofold) with no detectable effect on RN ase M RP function. Depletion of Pop8p protein also led to an RN ase MRP RN A reduction, but only 4-fold, compared with a 7- to 13-fold loss of RN ase MRP RNA observed with the other Pop protein and Rpplp depletions. Persistence of the RNase P RNA precursor band in all the depl etions could reflect continuing synthesis of the precursor but failure of the holoenzyme to assemble and 
mature properly. The chromatographic behavior of the ribonucleoprotein containing the RPR 1 RNA precursor previously caused us to speculate that it was assembled into an RN P similar to the mature enzyme before terminal processing. Lack of accumulation of mature RNAs is consistent with the inability of the precursor to assemble into an RNP complex in the depleted strains.

Defects in 5.8S rRNA precursor accumulation are detectable upon depl etion of Pop5p, Pop6p, and Pop7p

The characterized precursors of the 5.8S rRNA mature forms containing internal transcribed spacer (ITS1) sequences are depicted in Figure 3A. In wild-type strains a ratio of $\sim 10: 1$ exists between the $5.8 \mathrm{~S}(\mathrm{~S})$ (short) and $5.8 \mathrm{~S}(\mathrm{~L})$ (long) mature rRNAs. RN ase MRP mutations typically result in a shift in the ratios of the short and long forms to approximately 1:1. In addition, a 5'-extended form of the 5.8S rRNA with additional ITS1 sequences, 5.8S(VL) (very long), accumulates in RN ase MRP mutants (Lygerou et al. 1994; Chu et al. 1997; Dichtl and Tollervey 1997). Depletion of three of the five uncharacterized candidate RNase P subunits, Pop5p, Pop6p, and Pop7p, in addition to the previously characterized Rpplp, shows a clear shift in the ratio of the $5.8 \mathrm{~S}(\mathrm{~S})$ to $5.8 \mathrm{~S}(\mathrm{~L})$ rRN As and accumulation of the very long form of the 5.8S rRN A intermediate, 5.8S(VL), relative to the wild-type strain (Fig. 3B). N either GAL::rpr2 nor GAL::pop8 strains show a 5.8(S):5.8(L) shift, suggesting the depleted proteins might be RN ase P-specific subunits. However, further immunoprecipitation experiments showed that Pop8p, but not Rpr2p, was physically associated with both RN ase $P$ and RN ase MRP RNA subunits. From these data it appears that the moderate lowering of the RN ase MRP RN A level seen with Pop8p depl etion is not sufficient to cause RN ase MRP cleavage to become rate-limiting and lead to the accumulation of alternately processed $5.8 \mathrm{~S}$ forms.

\section{Epitope-tagged Rpr2p immunoprecipitated in association with only RNase P RNA}

To characterize further the association of the large number of protein subunits shared between RN ase $\mathrm{P}$ and RN ase MRP, each of the carboxyl termini of the newly identified subunits was tagged with a Flag epitope. Solubl e cell extracts were prepared from each of the haploid yeast strains harboring an epitope-tagged RN ase P protein as the sole source of that subunit. The immunoprecipitates obtained from the extracts using anti-Flag antibody were anal yzed by $\mathrm{N}$ orthern bl ot using probes to RN ase $P$ and RN ase M RP RN As (Fig. 4). Both Pop5p and Pop8p were precipitated in association with RN ase $P$ and RN ase MRP RNAs, indicating that these proteins are subunits of both complexes. Even though Pop8p deple ti on had little observable effect on RN ase M RP function, it has been tentatively designated a Pop protein on the basis of physical association with both RN ase $P$ and RNase MRP RNAs, in addition to the partial RNase MRP RNA reduction seen with Pop8p depletion. Pop7p was found in a complex with the precursor to RN ase $P$ RNA (pre-P RN A) and RN ase M RP RN A, but little or no mature RNase P RNA coprecipitated. Although this might indicate an association with only the pre-RN ase $P$ RNA, the purification of Pop7p with mature RN ase $P$ holoenzyme supports the likelihood that the Flag epitope is not exposed in the mature RN ase P complex. Rpr2p immunoprecipitated with only RNase P RNAs, mature and precursor forms, consistent with the observation that its depletion affects RN ase P activity in pretRNA processing, but not RNase MRP activity in pre rRNA processing. Of the newly identified yeast subunits, only the Pop6p Flag tag could not be used to precipitate either RN ase P or RN ase M RP RN As. These data, and the purification of these subunits with RN ase $\mathrm{P}$ alone, are not consistent with a higher-order complex between RN ase P and RN ase MRP in cell extracts. In particular, immunoprecipitation results with tagged

Figure 4. Immunoprecipitations of protein subunits selectively coprecipitate RN ase $P$ and RN ase MRP RN A subunits. As shown schematically in Fig. 2, Rpplp, Pop5p, Pop6p, Rpr2p, Pop7p, and Pop8p were each expressed from plasmid gene copies in a strain where the chromosomal copy of that gene had been deleted. Recombinant proteins contained Flag epitope at the carboxyl termini. Soluble extracts were made from actively growing cultures of each strain and the parental wild type (WT) strain. Immunoprecipitation with highly specific monoclonal antibodies

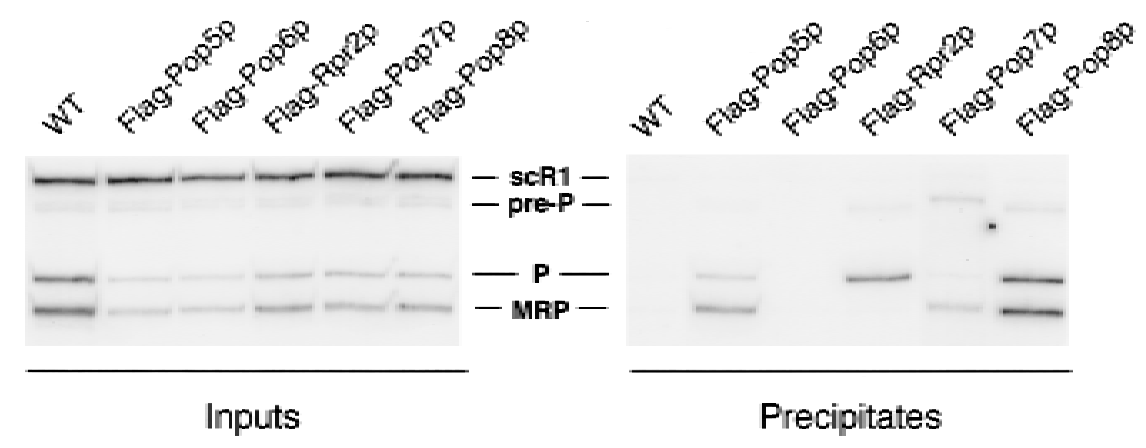
against the Flag epitope was followed by N orthern blot analysis for the abundance of precursor and mature RN ase P RN A (pre-P RN A and P RNA) and RN ase MRP RN A (MRP RNA). Signal recognition particle RN A (scR1) was used as a control for an RNA that was not expected to precipitate with any of the Flag-tagged proteins. (Left) The RNA content of the input fractions; (right) RN As found in the preci pitates. RN ase P and RN ase M RP RN As were not preci pitated in the wild-type (WT) strain or with the Flag tag on Pop6p. All three RN As (pre-P, P, and M RP) were precipitated with the Flag tag on Pop5p or Pop8p. Rpr2p and Pop7p gave differential coprecipitation of the RN As. Rpr2p coprecipitated only RN ase P RN As (pre-P and P). Pop7p coprecipitated with M RP and pre-P preferentially, bringing down relatively low levels of mature RN ase P RNA. 
Rpr2p and Pop7p suggest that the two enzymes can be immunoprecipitated independently.

Amino acid sequence of Pop5p-Pop8p and Rpr2p does not show significant similarity to any known proteins or RNA-binding motifs

All of the newly identified RN ase P subunits were anaIyzed for homology by pairwise alignment to the eubacterial RNase $\mathrm{P}$ proteins, their signature sequence (Bairoch et al. 1995), and the previously identified nuclear and mitochondrial RN ase $\mathrm{P}$ protein subunits. In addition, pairwise alignment was attempted between a variety of known tRN A processing enzymes and nucleolar antigens, including the genetically identified Snmlp subunit of RNase MRP. N one of the BLAST searches (Altschul et al. 1990) of the SGD, the SWISS-PROT database (Rodriguez-T ome et al. 1996), and PIR databases (Sidman et al. 1988) yielded significant matches, and only one pairwise alignment between Pop7p and nucleoIar antigen Rrp7p (Baudin-Baillieu et al. 1997) showed regions of significant similarity. Even in this case, however, no motif in the alignment could be identified (not shown).

A search for known motifs and sequence patterns has yielded limited information. No known RNA-binding motifs could be identified (Burd and Dreyfuss 1994), but most subunits possess regions rich in basic amino acids. The lysines and arginines in the newly identified RN ase $P$ subunit sequences are underlined in the sequences shown in Figure 5. Of the RN ase P proteins only Pop8p is acidic overall with a pl of 4.8; the remaining basic subunits have an average pl of 9.5. Every RN ase P protein subunit, except Rpplp, contains a pattern of two contiguous Iysine residues preceded or followed by an additional lysine at a distance of 3-8 intervening residues. Thelysines that conform to this pattern are indicated by bold lettering in Figure 5. Pop6p, Rpr2p, and Pop7p contain three of these regions. This Iysine pattern can be found in a number of ribosomal proteins with some in highly conserved regions of S8, S7, S21, and L25 (Burton et al. 1983; Rutgers et al. 1991; Sal azar et al. 1993; Engemann et al. 1995). These resi dues might be involved in protein-RNA association, as proposed for positively charged residues conserved in the Escherichia coli C5 protein subunit (Gopalan et al. 1997). Alternatively, the charged regions could be sites of protein-protein interactions or nuclear localization signals (Garcia-Bustos et al. 1991; Dingwall and Laskey 1992). The proposed lysine motif can also be found in Poplp at amino acids 616-623 (Lygerou et al. 1994), Pop3p at positions 10-20 and 183-192 (Dichtl and Tollervey 1997), and Pop4p as two overlapping occurrences at positions 97-111 (Chu et al. 1997).

\section{Discussion}

We have isolated eukaryotic nuclear RN ase $P$ to resolve the question of what components are associated with and necessary for function of the isolated RN ase $P$ en-

\section{Pop5p}

1 MVRLKKSRYIL FEIIFPPTDT MVEESVSKAD ILISHHBASP ADVSIKESILQ EIRRSLSLNL 61 GDYGSAKCNS LLOIKYFSNK TSTGIIBCHB EDCDLVIMAL MLMSEIGDVD GLIVNPVVVS 120 121 GTIKRIEQFA MBRNSKILNI IKCSQSSHLS DNDFIINDFE KIGBENENEN EDD 173

\section{Pop6p}

1 MINGYYYMEI SBDLDISSET QCLBFLKETV IPSLANNGNN STSIQYHGIS GMONIKXSVN 61 KIDROINMAD RSLGLQQVVC IFSYGPHIQR MLSILEIFKB GYIENNKGIY QWNELTSFDI 120 121 KREGBNELQE ERLEVPILVT IVSDSEIIDL NLHSETKO 158

\section{Rprep}

1 MGRKAHGGEM KRPEIDENGTL IVPPPETIAN QDHFHRLNYL YQISAYQTRA ROKARTDAHT 60 61 PLABNYI 121 KRENIGADPN YBTYSEREGN LLNS 144

\section{Pop7p}

1 MALKKNTHNK STKRVTEHPS LKTLTHKOIH TTIFVKSTTP YVSALKEING FLDSVHKOGS 61 SYVAVLGMGK AVEKTLALGC HFODOKNEIII EVYTETIEVL DEVITEGQAD IDMESDVEDD 12 121 DEETOLKKRA VSGVELEIYV 140

\section{Pop8p}

1 MGEKTFREWO YFKLSITSFD QDVDDAHAID QMTWBQWINM ALERSYGIFG EGVEYSFLHV G0 61 DDKLAYIRVI HADKDTFSSS ISTYISTDEI VGSPLTVSIL QESSSIBLLE VTDDDRLWLE 120 121 KVMEEEEQQDC KCI 133

Figure 5. Sequences of the protein subunits have little similarity to bacterial or mitochondrial RNase $\mathrm{P}$ proteins. The amino acid sequences of the five newly identified subunits are shown, as derived from the SGD (http://genome-www.stanford.edu/Saccharomyces/). Of the five ORFs, only POP8 contains a predicted intron, composed of 75 bp between the first and second base pair of the sixteenth codon of the ORF. PCR analyses using primers flanking the intron with genomic DNA and CDN A library confirm that the PO P8 CDN A gives a smaller PCR product by the expected amount. As discussed in the text, these sequences do not display strong similarities to other gene sequences in current databases and do not display notable similarities when aligned pairwise with each other or with other identified RN ase P or RN ase MRP proteins. Sequence features that are discussed in the text are indicated by underlining (lysines and arginines) or boldface type (lysine residues that form a short pattern in all RN ase P subunits except Rpplp).

zyme. The candidate polypeptides from previous work included Poplp, Pop3p, Pop4p, and Rpplp (Chu et al. 1997; Dichtl and Tollervey 1997; Stolc and Altman 1997). All four of these proteins were found in the purified fractions. Pop1p, Pop3p, and Pop4p had been identified first in genetic screens, and Rpplp had been identified by similarity to a human RN ase P-associated protein, Rpp30. It has been reported that Poplp did not appear to be a member of the RN ase $\mathrm{P}$ complex from a purification of the human enzyme (Eder et al . 1997; Stolc and Altman 1997). The data presented in this report demonstrate that Poplp is part of the yeast nuclear RN ase $P$ holoenzyme.

In addition to Pop1p, Pop3p, Pop4p, and Rpplp, five new protein subunits were identified with peptide se quences obtained by ion trap spectrometric analysis. The protein sequences of the corresponding ORFs were used to search databases but reveal ed no significant homol ogy to any known proteins from other organisms. In an attempt to reveal potential functional domains, pairwise alignments were performed with proteins associated with other RN ase $\mathrm{P}$ enzymes and RN ase MRP, including 
Snm1p (yeast RNase MRP-specific protein), Rpm2p (yeast mitochondrial protein), and the $C 5$ protein (E. coli RN ase $P$ protein subunit), as well as the sequence consensus for the bacterial RN ase P proteins (Gopalan et al . 1997). N one of these pairwise alignments reveal ed regions of obvious similarity to the RN ase P protein subunits.

Because one or more of the subunits must interact with the RN A subunit and could interact with the RNA substrate, a concerted attempt was made to identify RN A binding domains in the RN ase $\mathrm{P}$ proteins. $\mathrm{N}$ one of the reported RN A-binding domains were present. However, most of the proteins are very basic, and it was noted that eight of the nine RN ase P protein components contain a pattern of a lysine doublet with a third Iysine spaced 3-8 residues away. This region has charged residues in addition to lysine in a number of these proteins. A pattern search (Chervitz et al. 1997) revealed the presence of clustered lysine residues in conserved regions of several ribosomal proteins. The eubacterial RN ase P protein does not contain the lysine doublet pattern but does contain a conserved sequence between the single proteins of the different enzymes. The eubacterial consensus sequence is composed of positively charged residues thought to be involved in protein-RN A contact (Gopalan et al. 1997). Only one nucleolar yeast protein, Rrp7p (Baudin-Baillieu et al. 1997) was found to possess regions of notable homology to one of the eukaryotic subunits, Pop7p. Rrp7p is involved in production of the 18S rRN A and is thought to be required for correct assembly of the ribosomal protein S27 into the preribosomal particle. In a pairwise alignment amino acids 10-34 of Pop7p showed 33\% identity with positions 10-36 in Rrp7p, with a gap of 2 amino acids at positions 17-18 in the Pop7p sequence. Another region, amino aci ds 106-121 of Pop7p, was 44\% identical to the Rrp7p sequence spanning amino acids 195-210. These regions of identity do not contain the lysine doublet motif or other notable functional motifs.

The protein products of the newly identified RN ase $P$ subunit ORFs, Pop5p-Pop8p and Rpr2p, were shown to be essential for cell survival (Fig. 2). Depletion of these proteins from the cell resulted in the same pre-tRNA processing defects seen with mutation or depletion of previously proposed components, Poplp, Pop3p, Pop4p, and Rpplp (Fig. 3). Depletion of Pop5p-Pop7p of the newly identified subunits is al so concomitant with the defect in pre-rRN A processing at site A3 by RN ase M RP. This observation is consistent with cleavage defects observed at A3 with the depletion of Pop1p, Pop3p, Pop4p, and Rpplp (Lygerou et al. 1994; Chu et al. 1997; Dichtl and Tollervey 1997; Stolc and Altman 1997). Depletion of Pop8p did not give the characteristic ratio change of $5.8 \mathrm{~S}(\mathrm{~L})$ to $5.8 \mathrm{~S}(\mathrm{~S})$ as a result of a defect in processing at $A 3$ but did cause a four-fold reduction of the RN ase MRP RNA level upon extended depletion of Pop8p. The reduction in endogenous RN A levels from protein subunit depletion might not have reached a threshold level required for the 5.8S precursor processing defect or Pop8p might not be necessary for the 5.85 precursor processing function of RN ase MRP. Because RN ase $P$ and RN ase MRP RNAs also coimmunoprecipitate with epitopetagged Pop8p, we have tentatively assigned Pop8p as a subunit of both enzymes.

Only one protein, Rpr2p, gave results entirely consistent with an RN ase P subunit but not an RN ase MRP subunit. Depletion of Rpr2p did not give defects in RN ase MRP RN A levels or pre-rRNA processing but did depl ete mature RN ase P RN A, and caused expected pretRN A accumulations. Also, Rpr2p was found in association with precursor and mature RN ase $P$ RN A, but not RN ase MRP RNA, by immunoprecipitation of epitopetagged Rpr2p. Therefore, Rpr2p is the only protein specific to RN ase P. Similarly, there has been a report of one yeast protein specific to RN ase MRP, Snmlp (Schmitt and Clayton 1994), suggesting that the two enzymes might differ only in their divergent RNA subunit and one protein subunit with eight proteins held in common. Physical isolation of RN ase MRP will be necessary to determine its composition.

A profile of the purified nuclear RN ase $P$ holoenzyme and subsequent characterization of the protein subunits resolves the question of what proteins are biologically relevant to the function of this enzyme. However, there is remaining uncertainty as to whether RN ases $P$ and MRP are separate enzymes with many identical protein subunits or whether the enzymes share some subunits in vivo as part of a larger complex. From the data presented in this report it does not appear that subunits are shared on the basis of a common complex that is required for RN ase $P$ activity against pre-rRN A. Similarly, it appears from the work of others (Lygerou et al. 1996) that active RN ase M RP can be separated from the majority of RN ase P. Immunoprecipitation results with Flag-tagged Rpr2p and Pop7p suggest that the two enzymes are distinct complexes and can be precipitated independently.

The precise cellular location of nuclear $R N$ ase $P$ is not clear at present. RN ase MRP is a nucleolar enzyme (Jacobson et al. 1995; Matera et al. 1995), but there are reports that most of the mammalian RNase $\mathrm{P}$ is either nucleoplasmic (Jacobson et al. 1997) or at the periphery of nucleoli (M atera et al. 1995; B. Lee et al. 1996). Several observations would be consistent with nucleolar RN ase $P$ localization. It was shown previously that a yeast RN ase P RN A subunit mutation causes a pre-rRN A processing defect (Chamberlain et al. 1996a). Although this could be an indirect effect, the existence of eight proteins common to both RN ase $P$ and RN ase MRP suggests that at least some of the two enzymes might colocalize by virtue of signals in the proteins. Nucleolar localization of RN ase $P$ would suggest that some aspects of pre-tRN A processing occur at the nucleolus.

Although the eukaryotic RN ase $\mathrm{P}$ activity requires a greater contribution from protein than is provided by the single, small eubacterial protein subunit, it seems unlikely that nine protein subunits totaling $275 \mathrm{kD}$ compared with the 14-kD subunit in the eubacterial enzyme are all necessary for this activity. The complex subunit composition suggests that some of the protein subunits are important for functions other than pre-tRN A cleav- 
age and might be necessary to promote structural integrity or direct substrate interaction in compensation for I oss of catal ytic competence in the RNA subunit. In addition, the protein subunits could be responsible for broadening the RNA substrate specificity. The bacterial RN ase $P$ cleaves a number of substrates including other functional RNAs (Bothwell et al. 1976; Brown et al. 1990; Komine et al. 1994), a pre-mRNA (Alifano et al. 1994), and certain viral RN As (Green et al. 1988; Kikuchi et al. 1990; $M$ ans et al. 1990). This substrate range appears to be dependent on its protein subunit (Liu and Altman 1994). Although yeast nuclear RN ase P cleaves at several positions in the ITS regions of prerRNA in vitro, it is not clear that the minor effects RN ase $P$ mutations can have on 5.8S rRN A maturation are directly related to those cleavage si tes (Chamberlain et al. 1996a). We have not yet been able to demonstrate that RN ase $P$ mutations specifically affect maturation or turnover of any additional small RNA or pre-mRNA substrates.

The additional protein subunits in the nuclear RN ase $P$ might also have other functions including signaling, non-nucleolytic enzymatic activities, and subcellular localization. The identification of the protein subunits and the corresponding genes will facilitate a detailed investigation of the functions of the eukaryotic RN ase P holoenzyme.

\section{Materials and methods}

\section{RNase $P$ purification}

The protease-deficient strain PP1002 (MAT $\alpha$ ade2 leu2-3,112 pep4-3 rna3 rna82) was used as a source of RN ase $P$ (Lee and Engelke 1989). Extracts were prepared from 100 liters of saturated yeast culture in batches of 6 or 12 liters as described previously (Evans and Engelke 1990). The ammonium sulfate precipitate from the last step of the extraction protocol was dissolved in $25 \mathrm{ml}$ of HGMND (20 mM HEPES at pH 7.9, $10 \mathrm{~mm}$

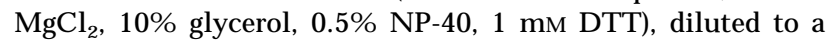
conductivity equival ent to $0.15 \mathrm{M} \mathrm{KCl}$, and applied to $8 \mathrm{ml}$ of SP-Sepharose (Pharmacia) per original liter of cell culture. The resin was washed with $\mathrm{HGMND}$ containing $0.15 \mathrm{M} \mathrm{KCl}$ and eluted in a single step with $\mathrm{HGMND}$ containing $0.4 \mathrm{M} \mathrm{KCl}$. The peak protein fractions were pooled, adjusted to $0.1 \mathrm{M} \mathrm{KCl}$, and applied to a $300 \mathrm{ml}$ DEAE cellulose (Whatman DE52) column and eluted with $0.45 \mathrm{M} \mathrm{KCl-HGMND}$ in a single step. RN ase $P$ activity was assayed as described below starting at this stage.

Fractions containing RN ase $P$ activity were pooled, diluted to $0.28 \mathrm{M} \mathrm{KCl}$ and half was applied to each of two $6 \mathrm{ml} \mathrm{M}$ ono Q columns (Pharmacia). Following extensive washing with $0.28 \mathrm{M}$ $\mathrm{KCl}-\mathrm{HGMND}$, an 80-ml linear gradient of $0.28-0.85 \mathrm{M} \mathrm{KCl}$ was used for elution. Fractions of $1 \mathrm{ml}$ were collected and analyzed for activity, protein, and RNA content. The RN ase P activity eluted between 0.38 and $0.5 \mathrm{M} \mathrm{KCl}$. Fractions containing the peak of RN ase $\mathrm{P}$ activity from the two $\mathrm{M}$ ono $\mathrm{Q}$ columns were applied to a 1-ml M ono S column in HGMND containing 0.12 $\mathrm{M} \mathrm{KCl}$. After washing with $0.12 \mathrm{M} \mathrm{KCl-HGMND}$, a 25-ml linear gradient of $0.12-0.9 \mathrm{M} \mathrm{KCl}$ resulted in elution of RN ase $\mathrm{P}$ activity between 0.2 and $0.3 \mathrm{M} \mathrm{KCl}$. Fractions of $0.5 \mathrm{ml}$ were collected and analyzed. The Mono S fractions with RN ase P activity were applied to four 34-ml glycerol gradients of $15 \%$ $25 \%$ in HGMND (DTT at $0.1 \mathrm{~mm}$ ). The first half and second half of the M ono S activity peak fractions were layered on top of different glycerol gradients because protein gel s showed that the two hal ves of the M ono S peak had different contaminants. The same protein bands were observed in the glycerol gradient peak activity fractions in both cases. Gradients were spun at $96,500 \mathrm{~g}$ $(27,000 \mathrm{rpm})$ for $30 \mathrm{hr}$ at $4^{\circ} \mathrm{C}$ in a SW28 rotor (Beckman). Fractions of $1 \mathrm{ml}$ were collected by puncture of the Ultraclear ultracentrifuge tubes near the bottom with a 12-gauge hypodermic needle.

RNase $P$ activity assay

An internally ${ }^{32} \mathrm{P}$-label ed pre-tRN $\mathrm{A}^{\mathrm{Asp}}$ substrate (Hollingsworth and $M$ artin 1987) was prepared, and RN ase $P$ activity assays were conducted as described (Chamberlain et al. 1996a). Specific activity determinations were obtained by electrophoretic separation of the substrate and products on $12 \%$ denaturing pol yacrylamide gels (Sequegel) and anal ysis of products by Phosphorlmager (M olecular Dynamics). One unit of activity was defined as the amount of RN ase P activity necessary to cleave $10 \%$ of 1 pmole of the substrate under standard assay conditions.

\section{Protein quantitation and analysis}

Quantitation of yeast extract and column fractions was performed using the Micro BCA protein quantitation kit with a range of sensitivity of $0.5-20 \mu \mathrm{g}$ (Pierce). Estimates for final total protein from the glycerol gradient were made based on silver stain showing approximately equimolar levels of putative protein subunits and quantitation of the RN ase P RN A subunit by N orthern blot (see RNA analysis). All fractions from two glycerol gradients were analyzed by SDS-PAGE to assess the level of purification and to approximate the size of candidate subunits. The gel shown in Figure $2 \mathrm{C}$ was a Ready Gel (Bio-Rad) with gradient acrylamide concentration of $10 \%-20 \%$. A sample size of $20 \mu \mathrm{l}$ or $2 \%$ of each fraction was applied to each well of multiple gels. No protein was detected in the first five fractions from the bottom of the gradient and their analyses are not shown in Figure 2. The proteins and RN A were visualized using the Silver Stain Plus kit (Bio-Rad). Silver-stained el ectrophoretic protein standards (6.5-180 kD) were run in parallel (Sigma).

\section{RNA analysis}

For detection of RN ase P RNA in the glycerol gradient fractions an al iquot of each fraction was prepared and analyzed by $\mathrm{N}$ orthern blot as described (Chamberlain et al. 1996a). Hybridization probes included ${ }^{32} \mathrm{P}$-labeled antisense RPR1 RNA (RNase P RNA) and NME1 RNA (RN ase MRP RNA), and an oligodeoxynucl eotide probe complementary to $\mathrm{S}$. cerevisiae mitochondrial RN ase P RN A. The absolute concentration of RN ase P RN A in various fractions was determined by including, on the same blot, a titration of known concentrations of pure RPR1 RNA produced by T7 RNA polymerase in vitro using cRPR1-pGB plasmid. This plasmid construct contained an EcoRI-Smal fragment of the RPR1 gene cloned into pGEM-3Z (Promega) (Lee and Engel ke 1989). Oligodeoxynucl eotide probes used for detection of 5.8 rRN A and scR1 RN A (Felici et al. 1989) were $5^{\prime}{ }^{32} \mathrm{P}$ CGCATTTCGCTGCGTTCTTCATCG-3' and 5'-32P-GGCGTGCAATCCGTGTCT-3', respectively.

Protein sequence and analysis

In preparation for SDS-PAGE separation, $10 \mathrm{ml}$ of fractions 6-8 of the glycerol gradients were precipitated with a defined methanol/chloroform/water mixture (Wessel and Flügge 1984) 
and resuspended in $30 \mu \mathrm{l}$ of $2 \%$ SDS. Following separation by SDS-PAGE (12\%), proteins were stained with Coomassie blue and excised as individual band(s). After in gel reduction and S-carboxyamidomethylation, the band(s) were subjected to in gel tryptic digestion (Promega) and a single $10 \%$ or $20 \%$ al iquot from each was analyzed as follows. Sequence information was determined by microcapillary $(75 \mu \mathrm{m} \times 10-\mathrm{cm}$ column, packed in-house) reverse-phase chromatography coupled to the el ectrospray ionization (ESI) source of a quadrupole ion trap mass spectrometer (Finnigan LCQ, San Jose, CA) as in N ash et al. (1996). The instrument was programmed to acquire successive sets of three scan modes consisting of full scan mass spectrometry (MS) over the mass-to-charge ratio range 395-1200 atomic mass units; followed by two data-dependent scans on the most abundant ion in that full scan. These data-dependent scans allowed the automatic acquisition of a high-resolution (zoom) scan to determine charge state and exact mass and collisionally induced dissociation (CID) spectra for pepti de sequence information. Interpretation of the resulting MS/MS spectra of the peptides was facilitated by searching the yeast protein database with the algorithm SEQUEST (Eng et al. 1994). Base peak zoom scan ion intensities corresponded to a load of 25-200 fmoles by comparison with the average ion abundance of a standard peptide mixture analyzed under identical conditions. Pairwise sequence alignments of proteins identified in the SGD (Cherry et al. 1996) were performed using the computer program Lasergene.

\section{Gene disruption and epitope tagging of proteins}

PCR-based gene disruptions were carried out as described previously in Wach et al. (1994). Gene sequence for candidate proteins from the SGD were disrupted by replacing their entire ORFs with the kanM $\times 2$ module. Previous identifications of the ORFs for the newly identified subunits in the SGD were YAL033W (Pop5p), YGR030C (Pop6p), YIR015W (Rpr2p), YBR167C (Pop7p), and YBL018C (Pop8p). The kan $^{r}$ gene was inserted at the indicated loci in di ploid W303 (Lee et al. 1991) by homologous recombination using DN A fragment termini identical to the $50 \mathrm{bp}$ immediately upstream and downstream of the ORF. Correct disruption of alleles was verified by yeast colony PCR using oligonucleotides within the $\operatorname{kan}^{r}$ gene to oligonucleotides outside the deleted ORFs. Tetrads were dissected from sporulated heterozygous diploids to test viability.

The PCR fragments for indicated gene ORFs were subcloned into the Xmal and Sall site of yeast expression vector, p413GAL (gift of D. Thiele, University of Michigan, Ann Arbor) containing the GAL1 promoter and CYC1 terminator. RNA was isolated from these constructed strains (Rose et al. 1990). Two versions of each ORF were expressed, either precise reproduction of the endogenous sequence or with the Flag epitope tag (N-DYKDDDDK-C) added precisely to the carboxyl terminus. Both versions conferred viability for all ORFs tested. p413GAL was constructed from p413GPD (Mumberg et al. 1995) by replacing the Sacl-BamHI GPD promoter fragment with EcoRI (end-filled)-BamHI GAL1 promoter fragment. The expression constructs were transformed into appropriate heterozygous disrupted diploids. Haploid spores carrying the disrupted genomic allele and the corresponding functional plasmid copy with the GAL1 promoter were identified by selecting spores resistant to G418 and unable to grow on sel ective media containing glucose. Whole-cell yeast protein extraction and immunoprecipitation of the Flag-tagged proteins were performed as described in Chu et al. (1997) and Schmitt and Clayton (1994), with minor modifications. A $10-\mathrm{ml}$ culture was grown in SD-his to $\mathrm{OD}_{600}$ $\mathrm{nm}=0.7$ and washed with water and buffer $\mathrm{A}(50 \mathrm{mM}$ Tris- $\mathrm{HCl}$ at pH 7.4, $150 \mathrm{~mm} \mathrm{~N} \mathrm{aCl}, 5 \mathrm{~mm}$ EDTA, 0.1\% Triton X-100, 10\% glycerol, $1 \mathrm{~mm}$ DTT, $1 \mathrm{~mm}$ PMSF). Cells were opened and treated as described in Chu et al. (1997) and Schmitt and Clayton (1994). Anti-Flag M 2 affinity gel (Kodak) $(50 \mu \mathrm{l})$ was prepared according to the manufacturers recommendations. Whole-cell extract $(40 \mu \mathrm{l})$ was applied and treated as described in Chu et al. (1997) and Schmitt and Clayton (1994) to obtain RN A from the bound complexes.

\section{Acknowledgments}

We are grateful to Ann Kendall and Paul Good for their technical assistance and R. Robinson, E. Spooner, K. Pierce, and D. Kirby for expert mass spectrometric sequence analysis. We thank Robert Fuller, Dennis Thiele, Ron Taussig, William Ziehler, and Felicia Houser-Scott for advice and critical evaluation of the manuscript. This work was supported by $\mathrm{N}$ ational Institutes of Health (NIH) Grant RO1 GM 34869 (to D.R.E.). Oligonucleotide synthesis was subsidized by NIH grant P30CA46592 to the University of Michigan Cancer Center. J.R.C. was supported in part by $\mathrm{NIH}$ predoctoral training grant T32 GM 07315 awarded to the Cellular and Molecular Biology Graduate Program.

The publication costs of this article were defrayed in part by payment of page charges. This article must therefore be hereby marked "advertisement" in accordance with 18 USC section 1734 solely to indicate this fact.

\section{References}

Alifano, P., F. Rivellini, C. Piscitelli, C.M. Arraiano, C.B. Bruni, and M.S. Carlomagno. 1994. Ribonuclease E provides substrates for ribonucl ease P-dependent processing of a polycistronic mRN A. Genes \& Dev. 8: 3021-3031.

Altman, S., L. Kirsebom, and S.J. Tal bot. 1995. Recent studies of RN ase P. In tRNA: Structure, biosynthesis, and function (ed. D. Söll and U.L. RajBhandary), pp. 67-78. American Society of Microbiology, Washington, D.C.

Altschul, S.F., W. Gish, W. Miller, E.W. M yers, and D.J. Lipman. 1990. Basic local alignment search tool. J. Mol. Biol. 215: 403-410.

Bairoch, A., P. Bucher, and K. Hofmann. 1995. The PROSITE database, its status in 1995. Nucleic Acids Res. 24: 189-196.

Bartkiewicz, M., H. Gold, and S. Altman. 1989. Identification and characterization of an RNA molecule that copurifies with RNase P activity from HeLa cells. Genes \& Dev. 3: 488-499.

Baudin-Baillieu, A., D. Tollervey, C. Cullin, and F. Lacroute. 1997. Functional analysis of Rrp7p, an essential yeast protein involved in pre-rRN A processing and ribosome assembly. Mol. Cell Biol. 17: 5023-5032.

Bothwell, A.L., R.L. Garber, and S. Altman. 1976. Nucleotide sequence and in vitro processing of a precursor molecule to Escherichia coli 4.5 S RN A. J. Biol. Chem. 251: 7709-7716.

Brown, J.W., D.A. Hunt, and N.R. Pace. 1990. Nucleotide sequence of the 10Sa RNA gene of the $\beta$-purple eubacterium Alcaligenes eutrophus. Nucleic Acids Res. 18: 2820.

Burd, C.G. and G. Dreyfuss. 1994. Conserved structures and diversity of functions of RNA-binding proteins. Science 256: 615-621.

Burton, Z.F., C.A. Gross, K.K. Watanabe, and R.R. Burgess. 1983. The operon that encodes the sigma subunit of RNA polymerase also encodes ribosomal protein S21 and DNA primase in E. coli K12. Cell 32: 335-349.

Chamberlain, J.R., E. Pagán-Ramos, D.W. Kindelberger, and D.R. Engelke. 1996a. An RN ase P RNA subunit mutation 
that affects ribosomal RNA processing. Nucleic Acids Res. 24: 3158-3166.

Chamberlain, J.R., A.J. Tranguch, E. Pagán-Ramos, and D.R. Engelke. 1996b. Eukaryotic nuclear RN ase P: Structures and functions. In Progress in nucleic acids research and molecular biology (ed. K. M oldave and W. Cohn), pp. 87-119. Academic Press, San Diego, CA.

Chen, J.L. and N.R. Pace. 1997. Identification of the universally conserved core of ribonuclease P RNA. RNA 3: 557-560.

Cherry, J.M ., C. Adler, C. Ball, S. Dwight, S. Chervitz, Y. Jia, G. Juvik, S. Weng, and D. Botstein. 1996. Saccharomyces Genome Database. http://genome-www.stanford.edu/Saccharomyces/ 1996.

Chervitz, S.A., J.M. Cherry, and D. Botstein. 1997. Saccharomyces genome database on-line pattern matching program. http://genome-www.stanford.edu/Sacch3D / patmatch.html.

Chu, S., R.H. Archer, J.M. Zengel, and L. Lindahl. 1994. The RNA of RN ase MRP is required for normal processing of ribosomal RNA. Proc. Natl. Acad. Sci. 91: 659-663.

Chu, S., J.M. Zengel, and L. Lindahl. 1997. A novel protein shared by RN ase MRP and RN ase P. RNA 3: 382-391.

Dang, Y.L. and N.C. Martin. 1993. Yeast mitochondrial RN ase $P$. Sequence of the RPM 2 gene and demonstration that its product is a protein subunit of the enzyme. J. Biol. Chem. 268: 19791-19796.

Dichtl, B. and D. Tollervey. 1997. Pop3p is essential for the activity of the RN ase M RP and RN ase $P$ ribonucleoproteins in vivo. EMBO J. 16: 417-429.

Dingwall, C. and R. Laskey. 1992. Nuclear targeting sequences-a consensus? Trends Biochem. Sci. 16: 478-481.

Doersen, C.J., C. Guerrier Takada, S. Altman, and G. Attardi. 1985. Characterization of an RN ase $P$ activity from HeLa cell mitochondria. Comparison with the cytosol RNase P activity. J. Biol. Chem. 260: 5942-5949.

Doria, M., G. Carrara, P. Cal andra, and G.P. Tocchini Valentini. 1991. An RNA molecule copurifies with RN ase P activity from Xenopus laevis oocytes. Nucleic Acids Res. 19: 23152320.

Eder, P.S., R. Kekuda, V. Stolc, and S. Altman. 1997. Characterization of two scleroderma autoimmune antigens that copurify with human ribonuclease P. Proc. Natl. Acad. Sci. 94: 1101-1106.

Eng, J.K., A.L. M CCormick, and J.R.I. Yates. 1994. An approach to correlate tandem mass spectral data of peptides with amino acid sequences in a protein database. J. Am. Soc. Mass Spectrom 5: 976-989.

Engemann, S., E. Herfurth, U. Briesemeister, and B. WittmannLiebold. 1995. Amino acid sequence of the ribosomal protein HS23 from the halophilic Haloarcula marismortui and homology studies to other ribosomal proteins. J. Protein Chem. 14: 189-195.

Evans, C.F. and D.R. Engelke. 1990. Yeast extracts for transfer RNA gene transcription and processing. Methods Enzymol. 181: 439-450.

Felici, F., G. Cesareni, and J.M. Hughes. 1989. The most abundant small cytoplasmic RNA of Saccharomyces cerevisiae has an important function required for normal cell growth. Mol. Cell. Biol. 9: 3260-3268.

Forster, A.C. and S. Altman. 1990. Similar cage-shaped structures for the RNA components of all ribonuclease $P$ and ribonuclease MRP enzymes. Cell 62: 407-409.

Garcia-Bustos, J., J. Heitman, and M.N . Hall. 1991. N uclear protein localization. Biochim. Biophys. Acta 1071: 83-101.

Goffeau, A., B.G. Barrell, H. Bussey, R.W. Davis, B. Dujon, H. Feldman, F. Galibert, J.D. Hohei sel, C. Jacq, M. Johnston, E.J.
Louis, H.W. Mewes, Y. M urakami, P. Philippsen, H. TetteIin, and S.G. Oliver. 1996. Life with 6000 genes. Science 274: 563-567.

Gold, H.A., J.N. Topper, D.A. Clayton, and J. Craft. 1989. The RNA processing enzyme RN ase MRP is identical to the Th RN P and related to RN ase P. Science 245: 1377-1380.

Gopalan, V., A.D. Baxevanis, D. Landsman, and S. Altman. 1997. A nalysis of the functional role of conserved residues in the protein subunit of ribonuclease $P$ from Escherichia coli. J. Mol. Biol. 267: 818-829.

Green, C.J., B.S. Vold, M .D. M orch, R.L. Joshi, and A.L. Haenni. 1988. Ionic conditions for the cleavage of the tRNA-like structure of turnip yell ow mosaic virus by the catal ytic RN A of RN ase P. J. Biol. Chem. 263: 11617-11620.

Guerrier-Takada, C., K. Gardiner, T. Marsh, N. Pace, and S. Altman. 1983. The RNA moiety of ribonuclease $P$ is the catalytic subunit of the enzyme. Cell 35: 849-857.

Hansen, F.G., E.B. Hansen, and T. Atlung. 1985. Physical mapping and nucleotide sequence of the rnpA gene that encodes the protein component of ribonuclease P in Escherichia coli. Gene 38: 85-93.

Harris, M.E., A.V. Kazantsev, J.L. Chen, and N.R. Pace. 1997. A nalysis of the tertiary structure of the ribonuclease $P$ ribozyme-substrate complex by site-specific photoaffinity crosslinking. RNA 3: 561-576.

Harris, S.D., J. Cheng, T.A. Pugh, and J.R. Pringle. 1992. Molecular analysis of Saccharomyces cerevisiae chromosomel. On the number of genes and the identification of essential genes using temperature-sensitive-lethal mutations. J. Mol. Biol. 225: 53-65.

Hollingsworth, M.J. and N.C. Martin. 1986. RN ase P activity in the mitochondria of Saccharomyces cerevisiae depends on both mitochondrion and nucleus-encoded components. Mol. Cell Biol. 6: 1058-1064.

- - - 1987. Alteration of a mitochondrial tRN A precursor $5^{\prime}$ leader abolishes its cleavage by yeast mitochondrial RN ase P. Nucleic Acids Res. 15: 8845-8860.

Jacobson, M.R., L.G. Cao, Y.L. Wang, and T. Pederson. 1995. Dynamic localization of RN ase MRP RNA in the nucleolus observed by fluorescent RN A cytochemistry in living cells. J. Cell. Biol. 131: 1649-1658.

Jacobson, M.R., L.G. Cao, K. Taneja, R.H. Singer, Y.L. Wang, and T. Pederson. 1997. N uclear domains of the RN A subunit of RN ase P. J. Cell Sci. 110: 829-837.

Jayanthi, G.P. and G.C. Van Tuyle. 1992. Characterization of ribonuclease $\mathrm{P}$ isolated from rat liver cytosol. Arch. Biochem. Biophys. 296: 264-270.

Kikuchi, Y., N. Sasaki, and Y. Ando-Y amagami. 1990. Cleavage of tRN A within the mature tRN A sequence by the catalytic RNA of RN ase P: Implication for the formation of the primer tRN A fragment for reverse transcription in copia retroviruslike particles. Proc. Natl. Acad. Sci. 87: 8105-8109.

Komine, Y., M. Kitabatake, T. Yokogawa, K. Nishikawa, and H. Inokuchi. 1994. A tRN A-like structure is present in 10Sa RNA, a small stable RNA from Escherichia coli. Proc. Natl. Acad. Sci. 91: 9223-9227.

Lawrence, N., D. Wesolowski, H. Gold, M. Bartkiewicz, C. Guerrier-Takada, W.H. McClain, and S. Altman. 1987. Characteristics of ribonuclease $P$ from various organisms. Cold Spring Harbor Symp. Quant. Biol. 52: 233-238.

Lee, B., A.G. Matera, D.C. Ward, and J. Craft. 1996. Association of RN ase mitochondrial RNA processing enzyme with ribonuclease $P$ in higher ordered structures in the nucleolus: $A$ possible coordinate role in ribosome biogenesis. Proc. Natl. Acad. Sci. 93: 11471-11476.

Lee, J.Y. and D.R. Engelke. 1989. Partial characterization of an 
RN A component that copurifies with Saccharomyces cerevisiae RN ase P. Mol. Cell Biol. 9: 2536-2543.

Lee, J.Y., C.E. Rohlman, L.A. Molony, and D.R. Engelke. 1991. Characterization of RPR1, an essential gene encoding the RNA component of Saccharomyces cerevisiae nuclear RN ase P. Mol. Cell Biol. 11: 721-730.

Lee, Y.C., B.J. Lee, D.S. Hwang, and H.S. Kang. 1996. Purification and characterization of mitochondrial ribonuclease $P$ from Aspergillus nidulans. Eur. J. Biochem. 235: 289-296.

Lipman, D.J. and W.R. Pearson. 1985. Rapid and sensitive protein similarity searches. Science 227: 1435-1441.

Liu, F. and S. Altman. 1994. Differential evolution of substrates for an RNA enzyme in the presence and absence of its protein cofactor. Cell 77: 1093-1100.

Lygerou, Z., P. Mitchell, E. Petfalski, B. Seraphin, and D. Tollervey. 1994. The POP1 gene encodes a protein component common to the RN ase MRP and RN ase P ribonucleoproteins. Genes \& Dev. 8: 1423-1433.

Lygerou, Z., C. Allmang, D. Tollervey, and B. Séraphin. 1996. Accurate processing of a eukaryotic precursor ribosomal RN A by ribonuclease M RP in vitro. Science 272: 268-270.

Mans, R.M., C. Guerrier Takada, S. Altman, and C.W. Pleij. 1990. Interaction of RN ase $P$ from Escherichia coli with pseudoknotted structures in viral RN As. Nucleic Acids Res. 18: 3479-3487.

Matera, A.G., M.R. Frey, K. Margelot, and S.L. Wolin. 1995. A perinucleolar compartment contains several RNA polymerase III transcripts as well as the polypyrimidine tract-binding protein, hnRN P I. J. Cell Biol. 129: 1181-1193.

Morales, M.J., Y.L. Dang, Y.C. Lou, P. Sulo, and N.C. Martin. 1992. A 105-kDa protein is required for yeast mitochondrial RN ase P activity. Proc. Natl. Acad. Sci. 89: 9875-9879.

Morrissey, J.P. and D. Tollervey. 1995. Birth of the snoRN Ps: The evolution of RN ase M RP and the eukaryotic pre-rRN Aprocessing system. Trends Biochem. Sci. 20: 78-82.

Mumberg, D., R. M üller, and M. Funk. 1995. Yeast vectors for the controlled expression of heterologous proteins in different genetic backgrounds. Gene 156: 119-122.

Nash, H.M., S.D. Bruner, O.D. Scharer, T. Kawate, T.A. Addona, E. Spooner, W.S. Lane, and G.L. Verdine. 1996. Cloning of a yeast 8-oxoguanine DNA glycosylase reveals the existence of a base-excision DNA-repair protein superfamily. Curr. Biol. 6: 968-980.

Pace, N.R. and J.W. Brown. 1995. Evolutionary perspective on the structure and function of ribonuclease $P$, a ribozyme. J. Bacteriol. 177: 1919-1928.

Pearson, W.R. and D.J. Lipman. 1988. Improved tools for biological sequence comparison. Proc. Natl. Acad. Sci. 85: 2444-2448.

Reich, C., G.J. Olsen, B. Pace, and N.R. Pace. 1988. Role of the protein moiety of ribonuclease $\mathrm{P}$, a ribonucleoprotein enzyme. Science 239: 178-181.

Rodriguez-Tome, P., P.J. Stoehr, G.N . Cameron, and T .P. Flores. 1996. The European Bioinformatics Institute (EBI) databases. Nucleic Acids Res. 24: 6-12.

Rose, M.D., F. Winston, and P. Hieter. 1990. Methods in yeast genetics. Cold Spring Harbor Laboratory Press, Cold Spring Harbor, NY.

Rutgers, C.A., J.M.J. Rientjes, J. van't Reit, and H.A. Raué. 1991. rRN A binding domain of yeast ribosomal protein L25. Identification of its borders and a key leucine residue. J. Mol. Biol. 218: 375-385.

Salazar, C.E., D.M. Mills-Hamm, V. Kumar, and F.H. Collins. 1993. Sequence of a cDNA from the mosquito Anopheles gambiae encoding a homologue of human ribosomal protein S7. Nucleic Acids Res. 21: 4147.
Schmitt, M.E. and D.A. Clayton. 1993. Nuclear RN ase M RP is required for correct processing of pre-5.8S rRN A in Saccharomyces cerevisiae. Mol. Cell Biol. 13: 7935-7941.

. 1994. Characterization of a unique protein component of yeast RN ase MRP: An RNA-binding protein with a zinccluster domain. Genes \& Dev. 8: 2617-2628.

Shuai, K. and J.R. Warner. 1991. A temperature sensitive mutant of Saccharomyces cerevisiae defective in pre-rRN A processing. Nucleic Acid Res. 19: 5059-5064.

Sidman, K.E., D.G. George, W.C. Barker, and L.T. Hunt. 1988. The protein identification resource (PIR). Nucleic Acids Res. 16: 1869-1871.

Stohl, L.L. and D.A. Clayton. 1992. Saccharomyces cerevisiae contains an RN ase MRP that cleaves at a conserved mitochondrial RNA sequence implicated in replication priming. Mol. Cell Biol. 12: 2561-2569.

Stolc, V. and S. Altman. 1997. Rpp1, an essential protein subunit of nuclear $\mathrm{RN}$ ase $\mathrm{P}$ required for processing of precursor tRNA and 35S precursor rRNA in Saccharomyces cerevisiae. Genes \& Dev. 11: 2414-2425.

Thomas, B.C., L. Gao, D. Stomp, X. Li, and P.A. Gegenheimer. 1995. Spinach chloroplast RN ase P: A putative protein enzyme. Nucleic Acids Symp. Ser. 33: 95-98.

Tranguch, A.J., D.W. Kindel berger, C.E. Rohlman, J.Y. Lee, and D.R. Engel ke. 1994. Structure-sensitive RN A footprinting of yeast nuclear ribonuclease P. Biochemistry 33: 1778-1787.

Wach, A., A. Brachat, R. Pohlmann, and P. Philippsen. 1994. $\mathrm{N}$ ew heterologous modules for classical or PCR-based gene disruptions in Saccharomyces cerevisiae. Yeast 10: 1793-1808.

Wessel, D. and U.I. Flügge. 1984. A method for the quantitative recovery of protein in dilute solution in the presence of detergents and lipids. Anal. Biochem. 138: 141-143.

Westhof, E. and S. Altman. 1994. Three-dimensional working model of M 1 RNA, the catalytic RNA subunit of ribonuclease P from Escherichia coli. Proc. Natl. Acad. Sci. 91: 51335137.

Zimmerly, S., D. Drainas, L.A. Sylvers, and D. Söll. 1993. Identification of a 100-kDa protein associated with nuclear ribonuclease $P$ activity in Schizosaccharomyces pombe. Eur. J. Biochem. 217: 501-507. 


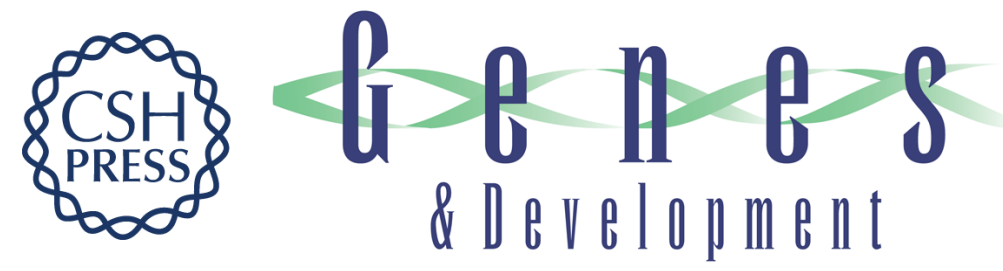

\section{Purification and characterization of the nuclear RNase P holoenzyme complex reveals extensive subunit overlap with RNase MRP}

Joel R. Chamberlain, Yoon Lee, William S. Lane, et al.

Genes Dev. 1998, 12:

Access the most recent version at doi:10.1101/gad.12.11.1678

References

This article cites 71 articles, 36 of which can be accessed free at:

http://genesdev.cshlp.org/content/12/11/1678.full.html\#ref-list-1

License

Email Alerting

Receive free email alerts when new articles cite this article - sign up in the box at the top

Service right corner of the article or click here.

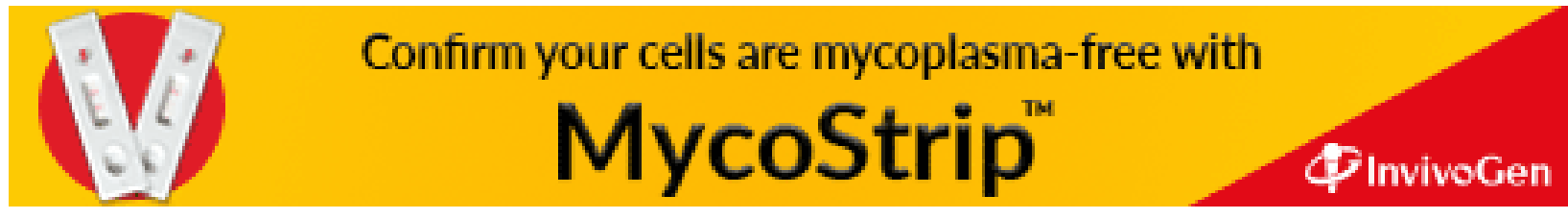

